\title{
Innovation Model of Merchant Involvement in Traditional Market Revitalization (Wonokromo Market Revitalization Study Surabaya)
}

\author{
Agus Prastyawan* \\ Department of Public Administration \\ Faculty of Social Sciences and Law \\ Universitas Negeri Surabaya \\ Surabaya, Indonesia \\ agusprstyawan@unesa.ac.id
}

\author{
Prasetyo Isbandono \\ Department of Public Administration \\ Faculty of Social Sciences and Law \\ Universitas Negeri Surabaya \\ Surabaya, Indonesia \\ prasetyoisbandono@unesa.ac.id
}

\author{
Noviyanti \\ Department of Public Administration \\ Faculty of Social Sciences and Law \\ Universitas Negeri Surabaya \\ Surabaya, Indonesia \\ noviyanti@unesa.ac.id
}

\begin{abstract}
Traditional markets are undoubtedly one of the drivers of the economy of a region. But unfortunately the existence of traditional markets is gradually fading because of competition from modern markets which are fully supported by policy makers and government officials. Instead of improving the standard of living of its merchant, the government and policy makers revitalize traditional markets that are no longer feasible without involving the community and merchant as stakeholders. The success of the Surabaya City Government through PD Pasar Surya in revitalizing the Wonokromo Market cannot be separated from the initial strategy by changing the status of the market service to PD Pasar Surya which is filled by professionals in their fields. The Surabaya City Government learned from the mistakes of the previous board of directors who were less active, minimal innovation and less assertive in dealing with Wonokromo Market merchant who were dominated by hard and temperamental Madurese ethnicity. The issue of revitalization began to be exhaled since 1993, 1996 and 2002 but failed to be implemented. With the entry of professionals in the board of directors in the period 2002-2006 and accompanied by an innovative and decisive approach, the Wonokromo Market revitalization program was successfully carried out with all its advantages and disadvantages.
\end{abstract}

Keywords: traditional market, modern market, innovation, involvement

\section{INTRODUCTION}

The role of the regional government in the classical perspective places itself as a service provider directly to the public through its public bodies. In the Wilson perspective assumes that local government will operate efficiently if it operates through a closed system, so that the consequence of citizen involvement in the administration of government is limited [1]. The policy is implemented from top to bottom through centralized planning inspired by a vision of the provider state or the state as a service provider [2]. The consequence of this approach is that the policies taken do not reflect transparency, accountability and negate public participation as a requirement for realizing good governance [3]. Pires defines that the adoption of a policy must involve stakeholders both public, private and voluntary sectors so that it will strengthen coordination between sectors, eliminate the obstruction of democratic channels and can increase accountability and legitimacy of the policy [4]. Stakeholder involvement will also have an impact on increasing positive employee attitudes, employee performance and operational and organizational performance [5].

This phenomenon is common in third world countries where the mechanism of governance through the development of development policy products tends to benefit groups that are more stable and economically established. This is not in line with the perspective of local governance which requires that the governance process must involve the local community as one of the stakeholders so that the resulting policy products can be in line with the expectations and needs of the local community. Local governance wants the development of synergy between the state, business and local communities, which is based on the capacity to build consensus, cooperate and accommodate each other based on mutual relations of equality in the process of governance

This condition has in turn resulted in bureaucratic behavior that tends to favor certain interests, compared to interests and problems that are actually faced by the public. As stated by Ratna that bureaucracy can actually be an extraordinary driving machine if it is able to be used to advance people's welfare[6]. But what is happening now is the opposite. In this context the real problem faced by the public (traditional market merchant) is the rapid growth of modern markets by $31.4 \%$, while traditional markets have a growth rate of $-8.1 \%$ [7]. The rapid growth of modern markets is felt by many who have an impact on the existence of traditional markets. On the one hand, the modern market is professionally managed with complete and convenient facilities. On the other hand, traditional markets are still struggling with the classic issues surrounding unprofessional management and the inconvenience of shopping. As expressed by Dwiyanto (2006) that many negative views formed regarding public organizations arise due to public dissatisfaction with the quality of services received from public organizations

The practice of market renovation and revitalization so far has mostly been in the name of merchant and often through direct appointment, according to the All-Indonesian Market Merchant Association (APPSI) the government often "betrays" old merchant. The experience during this renovation is only a cover to get rid of merchant who have been selling there. If this condition is left then the impact 
will appear widely (Kompas, 3 November 2007). But not all of the revitalization programs have negative access, there are several traditional markets in several cities that have been successfully revitalized without rejection, and even have the support of merchant such as the Klithikan Market in Solo and the Beringharjo Market in Jogjakarta. Retribution of traditional markets in the city of Solo after the revitalization actually increased significantly, namely from 7.8 billion to 19.2 billion [8].

Based on the explanation above, the researchers formulated the research problem as follows: "How is the innovation model of involving merchant in the revitalization of the Wonokromo Market?"

\section{METHOD}

The research design is a research plan and procedure which includes: from broad assumptions to detailed methods in data collection and analysis (Creswell, 2010). In this study a qualitative approach is used, where the understanding is as follows: "Qualitative research is a method for exploring and understanding the meaning by a number of individuals or groups of people ascribed to social or humanitarian problems. This qualitative research process involves important efforts, such as asking questions and procedures, gathering specific data from participants, analyzing data inductively starting from specific themes to general themes, and interpreting the meaning of data. The final report for this research has a flexible structure or framework. Who is involved in this form of research must apply an inductive-style research perspective, focus on individual meanings, and translate the complexity of an issue[9].

The focus of research is needed to know the criteria and inputs that provide information in the field, so that it can be known exactly which data is needed and collected and which data is omitted because it is considered irrelevant[10]. The focus of this research is: "Identification of the innovation model of involving merchant in the revitalization of the Wonokromo Market".

In accordance with the problems and focus of the study, the taking of the research location is planned in the city of Surabaya, especially in Surabaya Wonokromo Market.

Based on the focus of research, the sources of data in this study include informants, events and documentation. Sources of data in research are research subjects from which data originates[11]. Data sources in this study were informants, namely: Director of PD Pasar Surya, Chair of the Surabaya Market Merchant Association (AP3S), Chair of Wonokromo Market Merchant Collection (KPP), President Director of PT. Arwinto Intan Wijaya (AIW) and the Mayor of Surabaya. Other data sources are Legislation, Presidential Decree, Presidential Instruction, Minister of Trade and Industry Decree, Regional Regulations, Mayor Decrees, Report Book, results or minutes of meetings relating to various traditional market revitalization activities in Surabaya City.

\section{RESUltS AND DISCUSSION}

The policy of the city government in revitalizing traditional markets is faced with merchant' expectations regarding the form and results of revitalization. In this process the government has the authority to carry out the planned policies, on the other hand market merchant also have the right to accept or reject the policy before there is a dialogue. Moreover, changes to the layout and meaning of the traditional market to the modern market which certainly requires psychological and psychological readiness from the merchant. The involvement of merchant is needed so that their identities are not scattered by a policy from the policy holder.

Traditional markets will still have their own charm in the midst of modern society if managed properly by maintaining its unique and distinctive character. Even in some developed countries the existence of traditional markets has become a tourist destination for both citizens and tourists from abroad. Therefore, this dialectic of control process must be bridged so that the seeds of dispute do not occur which are detrimental to both parties. In modern political practice, the bridge that is built is in the form of dialogue. Through this dialogue the two parties can collide concepts, desires, hopes and results. This is what Habermas calls deliberative democracy, a democracy that is built on deliberation[12].

In the deliberations to reach consensus there is a dialectical process through a process of bargaining that shows their mutual rational motivation to defend economic, political, social and cultural interests which then produces a policy and finally becomes a reference frame for action. The involvement of merchant in the revitalization process will bring a joint commitment in achieving common goals. Commitment is considered as an opportunity to participate in making changes to an environment, all elements have the resources to participate and when all elements work together then the results of achievement are certainly greater than working individually[13].

Rahzen explained that historically Wonokromo is indeed an important area in the history of the development of the City of Surabaya[14]. Even some Wonokromo circles are believed to be the forerunner of the city of Surabaya. History records that Wonokromo was once a bustling area with a variety of activities ranging from industry, trade and even agriculture. The Wonokromo region grew and developed along with the construction of the City of Surabaya as an industrial and service city in the colonial era, especially in the late 19th and early 20th centuries, Surabaya was even touted as the largest industrial city in the Dutch East Indies. The existence of the Wonokromo Market at that time was considered to be the largest market in Southeast Asia [15].

Wonokromo Market is classified as a first class market according to PD Pasar Surya Surabaya, because it has a radius of service to exit the region and has a large number of merchant. Because of its status as a first-class market and its strategic location at the gate of the southern city of Surabaya, Wonokromo Market is famous as a trading center for merchant in Surabaya. Wonokromo Market occupies an area of $\pm 17,000 \mathrm{~m} 2$ with a building area of $\pm 10,392 \mathrm{~m} 2$ and a total number of stands and kiosks of $\pm 3,891$ consisting of 2,394 stands and 1497 kiosks with details of stand status as follows: 3525 active stands, 62 stands, sealed stands stands were withdrawn by 30 stands, empty stands were 252 stands and stands were contracted by 22 stands[8].

The total number of merchant is $\pm 2,345$ people dominated by Madurese (table 2). The existence of public 
facilities in the form of MCK is 42 units spread over 8 locations. Stairway access to the Wonokromo Market is 11 units and stairway access from the Wonokromo Market to DTC is 3 units (PD Market data in 2013). Based on the physical characteristics of the Wonokromo Market it is expected to be able to assist PD Pasar Surya in boosting PAD, where since it was first established after the revitalization in 2005 - 2011 there has been a significant increase in income.

Table 1. Wonokromo Market Retribution Income

\begin{tabular}{|l|l|l|}
\hline No & Years & Income (IDR) \\
\hline 1. & 2005 & 1.480 .126 .895 \\
\hline 2. & 2006 & 3.167 .110 .280 \\
\hline 3. & 2007 & 3.253 .020 .901 \\
\hline 4. & 2008 & 4.530 .243 .275 \\
\hline 5. & 2009 & 4.316 .595 .201 \\
\hline 6. & 2010 & 3.938 .656 .013 \\
\hline 7. & 2011 & 5.112 .476 .801 \\
\hline
\end{tabular}

The increase in revenue can be interpreted as an indicator of success (with all the more or less) the Surabaya City Government through PD Pasar Surya in revitalizing the Wonokromo Market. The traditional market revitalization agenda has actually been programmed and socialized to the Market Merchant Association (HPP) after the fire on May 26, 2002 by H. Jupri as the managing director of PD Pasar Surya from 1998-2002 along with the investors namely PT Arwinto Intan Wijaya (AIW) Widagdo and Ali Ali Deliberation, however, was foundered by the high resistance from the HPP which is a representation of Wonokromo Market merchant, so the revitalization cannot be implemented yet.

Seeing the urgency of revitalizing traditional markets and responding merchant who were not as expected, the Surabaya City Government innovated by changing the status of traditional market managers, namely from the market service to PD Solar Market through Regional Regulation No.1 of 1999 concerning First Amendment to Regional Regulation Number 101982 concerning the Establishment of a Regional Market Company.

The change in status from market services to regional companies has implications for policies in managing traditional markets in the city of Surabaya, which in the end of the 2002-2006 board of directors consisted of practitioners in their fields, no longer containing bureaucrats. With the composition of the board of directors filled by practitioners, it is expected that traditional market management will become more professional, where one of the objectives of forming regional companies is to support national economic growth and has the authority to make partnership agreements with individuals, business entities in the context of developing company business.

PD Pasar Surya as the manager of traditional markets in the city of Surabaya considers in the face of the rapid development of shopping centers in Surabaya as well as to improve the economic conditions of the middle and lower classes and also considering the condition of existing traditional markets which tend to be slum, irregular and insecure because inside the market is a gathering place for thugs (Radar Surabaya daily news, 17th October 2005). Reporting from newspaper Kompas at 3th November 2007, the only recipe that is considered effective to cure it is to carry out revitalization, without undertaking revitalization efforts, merchant feel the harsh reality of how their markets are becoming increasingly squashed by competition with modern stores.

Moreover, the Wonokromo Market has been established as an emergency market since burning for the fifth time in 1992 (but despite the status of an emergency market, consumers actually boomed) where as a result the fire scorched nearly three-quarters of the total market area (Radar Surabaya daily news, 17th October 2005), such a situation This makes it one of the reasons for PD Pasar Surya Surabaya to initiate the Wonokromo Market revitalization program. In line with the reasons stated by PD Pasar Surya, Surabaya City Government wants the revitalization of the Wonokromo Market with the aim of[16]:

1. Restructuring the old Wonokromo Market into a new, more modern market,

2. Help increase regional income,

3. Prevent and overcome negative impacts on the environment, and

4. Developing strategic spatial planning and its utilization in order to create better structuring conditions.

Hope PD Pasar Surya as the manager of the traditional market after the revitalization will later the buyers feel comfortable in shopping which then has an impact on improving the welfare of merchant and ultimately can increase regional income in accordance with the mandate of Perda No. 1 of 1999. On the other hand investors as PD Pasar Surya partners are required to carry out development activities in accordance with specified specifications and quality (Gapura Magazine, 2006).

While the legal basis for the implementation of revitalization comes from the leadership of the legislative body (Surabaya City DPRD) is a recommendation letter from the Chairperson of the Surabaya City DPRD on December 20, 2002 number: 55/2957/402.3/2002, concerning Recommendations on the Wonokromo Market Development and from the chief executive (Surabaya Mayor) ) is the principle agreement of the Mayor of Surabaya concerning: Approval in Principle of Rebuilding the Wonokromo Market on January 28, 2003 number: 511.2/331/402.1.2/2003 which contains the appointment of PT AIW as the sole investor to rebuild the Wonokromo Market.

Armed with a number of legal bases, PD Pasar Surya took strict action including forcibly dismantling hundreds of stands that stood on fire land on April 15, 2003 with the help of the Police, Army and Satpol PP as well as disbanding the existence of HPPs which were considered to hinder the revitalization program with Directors Decree Number 184 of 2002 dated 19 November 2002 concerning Revocation of Warrant Number 511.2/44/411.62/1983 concerning the Establishment of a Market Merchant Association in Markets in the Service Offices of the Regional Level Regional Municipality of Surabaya. 
In order to meet the principles of good governance and fulfill the principle of participation of PD Pasar Surya to legalize the establishment of the Market Merchant NonGovernmental Organization (LSPP), which is suspected as a counterparty organization of the HPP. LSPP took a stance to support PD Pasar Surya's plan to revitalize the Wonokromo Market, in fact most LSPP members were included in a comparative study program in October 2002 to Jakarta which was funded by PT AIW as an investor and facilitated by PD Pasar Surya to look at traditional markets that successfully revitalized. Whereas HPP is considered by PD Pasar as an anti-development group. With the support of the LSPP, PD Pasar Surya considers that they have involved merchant in the revitalization process so that they are considered to have fulfilled the principles of good governance (merchant participation) plus the support of the Surabaya City Government and the Surabaya City DPRD further strengthening their steps in revitalizing the Wonokromo Market.

Based on the data mentioned above, the majority of Wonokromo Market merchant are Madurese, for more details, see table 2 below:

Table 2. Percentage of Ethnic Merchant of the Wonokromo Market

\begin{tabular}{|l|l|l|}
\hline No. & Ethnic & Procent \\
\hline 1. & Javaness & $37 \%$ \\
\hline 2. & Madurese & $38 \%$ \\
\hline 3. & Others & $25 \%$ \\
\hline & Jumlah & $100 \%$ \\
\hline
\end{tabular}

\section{Source: The data of Wonokromo Market office}

The Madurese are known as hard, temperamental, hardworking, hardworking and religious people. Religious communities, they are required to obey the ulama and umaro (derived from Arabic which means leaders) in this context is the PD Surya Market leader, where there is a significant relationship between the level of religiosity to the level of involvement (adherence to the leader). In other words the more religious a person is, their motivation to work according to the rules will increase[17].

The PD Surya Surya Board of Directors is well aware of these characteristics, because the background of the directors comes from professionals who are accustomed to dealing with a variety of typical types of people. One of the directors who happened to be Madurese was Ahmad Ganis Poernomo who was the director of merchant coaching, thus enabling him to be able to communicate (using local languages) well with the merchant. With the existence of a good emotional bond between the two parties it will potentially achieve the goal of revitalization.

Armed with emotional closeness because based on ethnic similarity and the ability to understand the characteristics of the ethnic Madurese, the board of directors embraced LSPP who were considered to support them to socialize revitalization through several types of religious activities, for example: Istighosah, breaking the fast and tarawih together, tadarus, khotmil Qur'an every month and held a religious holiday commemoration with merchant who were considered pro-revitalization. The involvement of several merchant in each of the activities carried out by PD Pasar Surya was considered to have represented all Wonokromo Market merchant which in the end was also considered as legitimacy for PD Pasar Surya for the smooth implementation of revitalization. Whereas the HPP that was disbanded by PD Pasar Surya, which later they formed a new group of merchant with the name Market Merchant Group (KPP), were not involved at all.

The removal of the KPP by PD Pasar Surya in the revitalization process of the Wonokromo Market made the KPP more intensified in conducting "resistance", which over time the KPP discovered several PD Pasar Surya policies that allegedly violated regional regulations and reported them to the Surabaya City DPRD. So that in the end "forced" the Surabaya City Government to clarify it. The alleged violation was the emergence of a letter sent by the Surabaya City Council to the Mayor of Surabaya numbered: 511.2/357/436.3/2004 dated July 28, 2004 concerning: Revocation of the Decree of the Director of PD Pasar Surya No. 026 of 2004.

Based on the letter from the Surabaya City DPRD, the Surabaya Mayor sent a letter to the PD Surya Surya Managing Director numbered: 539/3241.1/436.2.1/2004 dated August 18, 2002 concerning: Revocation of the Decree of the Director of PD Pasar Surya Number 026 of 2004. PD Pasar Surya responds to the Surabaya Mayor's recommendation by sending a letter numbered 511.2/796/436.6.2/2004 August 19, 2004 with the subject: Sending Decree of the Revised SK 026/2004. The opportunity to present the draft on August 20, 2004, the reason PD Pasar Surya did this was as mandated by Regional Regulation No. 2 of 1999 concerning Management of Markets.

The Mayor of Surabaya again sent a letter to PD Pasar Surya with the same contents for the second time with the number: 539/3470/436.2.1/2004 dated August 27, 2004 concerning: Recommendation of Revocation of the PD Surya Surya Board of Directors Decree Number 026 of 2004. The contents of the letter reminded once again to the Managing Director of PD Pasar Surya to immediately implement the recommendations of the Surabaya City DPRD and subsequently in every policy making the Directors always carry out in accordance with the applicable laws and regulations.

The emergence of ripples due to revitalization finally forced the Surabaya City DPRD to summon PD Pasar Surya, PD Pasar Surya Supervisory Agency, Surabaya City Government, the chairperson of Wonokromo KPP and the chairman of the Surabaya Market Merchant Association (AP3S) Alliance to bridge the dispute. Surabaya City DPRD considers the political design of the Wonokromo Market revitalization to help merchant of the Wonokromo Market which was affected by the fire. In the end the mediation had not yet yielded satisfactory results for all parties, but the Surabaya City DPRD reminded merchant that the revitalization plan of the Wonoromo Market had fulfilled the prevailing laws and regulations including all the formal legal elements that had been fulfilled. So that all parties must respect and comply with all the shortcomings and advantages, the impact of revitalization that occurs will be used as an evaluation for the Surabaya City Government in carrying out other traditional market revitalization. 


\section{REFERENCES}

\section{CONCLUSIONS AND SUGGESTIONS}

The spirit of regional autonomy based on Law Number 22 of 1999 is actually an increase in the quality of services to the community, to realize quality services it is necessary to empower the regions by giving authority to the regions to take quick and appropriate steps according to regional needs. So that people increasingly feel an increase in service quality, but in the context of this study problems arise, especially in the mindset as if autonomy is a sovereignty that is a tool (media) for local governments/authorities to realize their sovereignty (sovereignity) rather than developing the main mission of autonomy itself is how to further empower merchant.

The success of the Surabaya City Government through PD Pasar Surya in revitalizing the Wonokromo Market cannot be separated from the initial strategy by changing the status of the market service to PD Pasar Surya which is filled by professionals in their fields. The Surabaya City Government learned from the mistakes of the previous board of directors who were less active, minimal innovation and less assertive in dealing with Wonokromo Market merchant who were dominated by hard and temperamental Madurese ethnicity. The issue of revitalization began to be exhaled since 1993, 1996 and 2002 but failed to be implemented. With the entry of professionals in the board of directors in the period 2002-2006 and accompanied by an innovative and decisive approach, the Wonokromo Market revitalization program was successfully carried out with all its advantages and disadvantages.

This success is considered a proud achievement for the Surabaya City Government, because the revitalization of the Wonokromo Market is a pilot project for other traditional markets in Surabaya. That is, when the revitalization program is successful, the program will be applied to other traditional markets in the city of Surabaya. Moreover, the Surabaya City DPRD fully supports the steps of the Surabaya City Government. The consideration of the Surabaya City DPRD in supporting the revitalization of traditional markets is partly because this development goal is for the economic development of the City of Surabaya, the Surabaya City DPRD may not interfere when its enthusiasm for economic growth, given the PD Pasar Surya in accordance with the mandate of Regional Regulation No. 1 of 1999 oriented to profit oriented which has a supervisory board and its responsibility to the Mayor of Surabaya. The active involvement of the Surabaya City DPRD especially Commission $\mathrm{E}$ will intensely emerge when ripples emerge for merchant who are dissatisfied with the revitalization.
[1] M. R. K. Muluk, Peta Konsep Desentralisasi dan Pemerintah Daerah. Surabaya: ITS Press, 2009.

[2] M. E. Koopmans and Et.al, "The Role of Multi-actor Governance in Aligning Farm Modernization and Sustainable Rural Development," J. Rural Stud., vol. XXX, pp. 1-11, 2017.

[3] United Nations Human Settlements Programme, Tools to Support Transparency in Local Governance. Kenya: UN-HABITAT and Bob Browne/Grass Roots Comic Company Ltd, 2004.

[4] S. M. Pires and T. Fidelis, "Local sustainability indicators in Portugal: assessing implementation and use in governance contexts," J. Clean. Prod., vol. 2015, no. 86, pp. 289-300, 2014.

[5] M. Lin, Wu Xioyi, and Ling Qian, "Assessing the Effectiveness of Empowerment on Service Quality: A Multi-level Study of Chinese Tourism Firms," Tour. Manag., vol. 61, pp. 411-425, 2017.

[6] M. Ratna, "Membenahi Mesin Birokrasi yang Karatan," Kompas, 2007.

[7] A. Nielson, Modern Supermarket (Terjemahan AW Mulyana). Jakarta: Fakultas Ekonomi Universitas Indonesia, 2004.

[8] A. Prastyawan, A. Suryono, M. Saleh Soeaidy, and K. Muluk, "Revitalization of Traditional Markets into a Modern Market in the Perspective of Local Governance Theory (Studies on Revitalization Wonokromo Market in Surabaya)," IOSR J. Humanit. Soc. Sci. Ver. IV, vol. 20, no. 9, pp. 1-6, 2015.

[9] J. W. Creswell, Research Design: Pendekatan Kualitatif, Kuantitaif, dan Mixed (Edisi Alih bahasa oleh Achmad Fawaid). Yogyakarta: Pustaka Pelajar, 2010

[10] A. Strauss and J. Corbin, Dasar-Dasar Penelitian Kualitatif: Tatalangkah dan Teknik-teknik Teoritisasi Data (Alih bahasa oleh Shodiq \& Muttaqiem). Yogyakarta: Pustaka Pelajar, 2009.

[11] L. Moleong, Metodologi Penelitian Kualitatif. Bandung: PT Remaja Rosdakarya, 2009.

[12] A. Himawan and Et.al., "Keterlibatan Warga dalam Pembentukan Ruang Publik (Analisa Pembentukan Ruang Publik dalam Revitalisasi Pasar Tradisional di Kota Surakarta),” J. Anal. Sosiol., vol. Oktober 20, no. 1, pp. 1-16, 2013.

[13] L. M. Harris, Empowerment and Involvement, Presented at the Thirty-first Annual Meeting of the Eastern Vascular Society, Savannah, Ga., vol. October. Elsevier Inc, 2017.

[14] A. I. Masitha., "Revitalisasi Pasar Wonokromo," Universitas Gadjah Mada, Yogyakarta, 2008.

[15] M. Legowo and Et.al, "Pedagang dan revitalisasi pasar tradisional di Surabaya," J. Masy. Kebud. dan Polit., vol. XXII (Apri, no. 2, 2009.

[16] C. Noviana and G. Linawati, "Analisis Reposisi Pasar Wonokromo Lama Menjadi Pasar Wonokromo-DTC," Surabaya, 2007.

[17] T. Kawa, "Centrality of religiosity versus civic involvement. The case of Poland, Communist and Post-Communist Studies," 